Research Article

\title{
Effect of Recycled Rubber on the Properties of Road Bitumen
}

\author{
Krzysztof Blażejowski, ${ }^{1}$ Barbara Gawdzik $\left(\mathbb{D}^{2},{ }^{2}\right.$ and Tadeusz Matynia ${ }^{2}$ \\ ${ }^{1}$ Orlen-Asfalt, ul. Chemików 7, 09-411 Płock, Poland \\ ${ }^{2}$ Faculty of Chemistry, Maria Curie-Skłodowska University, pl. Marii Curie-Skłodowskiej 3, 20-031 Lublin, Poland \\ Correspondence should be addressed to Barbara Gawdzik; barbara.gawdzik@umcs.lublin.pl
}

Received 27 March 2018; Revised 8 August 2018; Accepted 5 September 2018; Published 21 October 2018

Academic Editor: Carola Esposito Corcione

Copyright (C) 2018 Krzysztof Blażejowski et al. This is an open access article distributed under the Creative Commons Attribution License, which permits unrestricted use, distribution, and reproduction in any medium, provided the original work is properly cited.

\begin{abstract}
Commercially available road bitumen 50/70 (EN 12591) was modified by recycled rubber and synthetic poly(butadiene) in the presence of sulfur donor. Modification was carried out at $190^{\circ} \mathrm{C}$ and $220^{\circ} \mathrm{C}$. Under such conditions, devulcanization of rubber took place. Prolonged heating in the presence of sulfur caused that devulcanized rubber and poly(butadiene) to revulcanize. The influence of rubber concentration as well as temperature and time of the modification process on the properties of resulted bitumens was studied. The results show that proposed process modifies the properties of base bitumen very effectively. Particularly noteworthy are values of Fraass breaking points, melting temperatures, penetrations, and elastic recoveries.
\end{abstract}

\section{Introduction}

Improvements in bitumen properties have been achieved by selecting the proper starting crude or tailoring the refinery processes used to make asphalt. According to Becker et al. [1] there are only a few crudes that can produce very good bitumens and only a limited number of actions that can be taken to control the refining process to make improved bitumen product. More possibilities make modification processes. Air blowing makes bitumen harder. Fluxing agents or diluent oils are occasionally used to soften the asphalt $[2,3]$. The method that can significantly improve bitumen quality is the addition of polymers. Polymer modification of bitumen (PMB) has become a more accepted method for addressing pavement distresses. The heavier vehicle loads, higher traffic volumes, and increased tire pressure have forced road administration to explore polymer modification for asphalt pavement applications.

There are numerous categories of modifiers used for bitumen modification, e.g., block copolymers: styrenebutadiene (SB), styrene-butadiene-styrene (SBS), and styrene-ethylene/butylene-styrene (SEBS); polyolefins; reactive ethylene terpolymer (RET); ethylene-vinyl acetate (EVA); and crumb rubber [4-15]. Polymer modifiers for bitumen binders that contain a large percentage of butadiene
( $50 \%$ by mass or greater) exhibit improved low-temperature properties. This was observed as a decrease of their glass transition temperature $\left(T_{\mathrm{g}}\right)$. Bitumen-rubber mixtures have been shown to have useful properties with respect to distresses observed in bitumen concrete pavements. Most notably, at low temperatures, a large increase in viscosity and improved low-temperature cracking resistance has been measured $[2,13]$. Generally, rubber modification causes asphaltic materials to become tougher, and they reduced the tendency of the surface to crack and bleed and improved aggregate retention $[11,15]$. The results published by Wang $[16]$ indicate that the swollen rubber powder is mutually adhered to form a network structure and the matrix bitumen changes from a homogeneous body into a two-phase continuous blending structure system constituted by rubber powder and bitumen. In the review paper, it was found that regardless of temperature modification, the introduction of crumb rubber into the paving technology can not only solve the disposal issue of waste tires but also improve the performance of asphalt pavements, including reducing traffic noise [17].

This paper presents the results of bitumen modification. The modifiers used were recycled rubber and synthetic poly (butadiene). The purpose of the study was to determine if the final products would have properties comparable to the properties of polymers modified bitumen (PMB) if recycled 
rubber was used in the modification process. The introduction of rubber to asphalt was done in such a way that it could create a common network with polybutadiene during cross-linking with sulfur. In order to make possible joint cross-linking of rubber and polybutadiene, at the beginning, it was necessary to carry out devulcanization of rubber.

A study was made of the influence of rubber concentration, as well as the temperature and time of the modification process on the properties of resulted bitumens.

\section{Experimental}

2.1. Materials. Bitumen used in this study was manufactured by ORLEN Asphalt Sp. z o.o., Płock, Poland, and dust rubber from recycled tires that came from Orzeł S.A., Poniatowa, Poland, whereas biodiesel oil was bought at ORLEN gas station. Synthetic poly(butadiene) (SKD-ND) was purchased in the Brenntag Poland Sp. o.o company (Kędzierzyn-Koźle, Poland). The sulfur donor was from POCh (Gliwice, Poland). The rubber powder in the experiments presented here had granulation $0-0.4$ and $0-0.8 \mathrm{~mm}$. Poly(butadiene) was added as $12 \%$ solution in biodiesel oil.

2.2. Asphalt Modification. In a $3000 \mathrm{~cm}^{3}$ round bottomed three-necked flask equipped with a mechanical stirrer, a thermometer, and a reflux condenser, $1794 \mathrm{~g}$ of bitumen $(87 \%, \mathrm{w} / \mathrm{w})$ was placed together with $200 \mathrm{~g}$ of crumb rubber $(10 \%, w / w)$ and earlier prepared biodiesel solution of poly (butadiene) and the content was heated to $190^{\circ} \mathrm{C}$-the temperature which is necessary for the devulcanization of rubber [18-20]. After 1 hour of stirring, sulfur was added. Stirring was continued and the total heating time was respectively: $2,4,8$, and $16 \mathrm{~h}$. The same experiments were carried out at $220^{\circ} \mathrm{C}$ with bitumen containing $15 \%$ (w/w) of rubber [21]. After completion of the modification process, the bitumen was poured from the reactor and cooled to ambient temperature. The hot bitumen was poured into the tank through a set of 2 sieves.

All syntheses were repeated three times and the product was averaged.

2.3. Test Method. The standard tests used to determine the properties of bitumen are given below:

Penetration (Pen25) at $25^{\circ} \mathrm{C}$ was measured according to standard method (EN 1426). Penetration is the depth at which the penetrometer needle is immersed in the asphalt under test at a load of $100 \mathrm{~g}$ at $25^{\circ} \mathrm{C}$ for 5 seconds. Ring and ball $\left(\mathrm{SP}_{\mathrm{R} \& \mathrm{~B}}\right)$ softening point was determined according to EN 1427. The test consists in cutting the asphalt layer through a steel ball. The value of shear stress on the asphalt surface is $0.25 \mathrm{kPa}$. The asphalt softening point is the conventional asphalt transition temperature from the viscoelastic state to the viscous state. Penetration index (IP) was calculated according to EN 12591/Ann.A. The value of PI should range from around -3 for high temperature susceptible bitumens to around +7 for highly blown lowtemperature susceptible (high PI) bitumen [22]. The Fraass breaking point, characterizing the behavior of bitumens at low temperatures, was determined according to EN 12593. Determination of the breakthrough point consisted in cooling the steel plate with the asphalt layer and the bending test every 1 minute until the asphalt layer cracked. Increase of the softening point $\mathrm{SP}_{\mathrm{R} \& \mathrm{~B}}$ was measured with use of roller thin film oven tester (RTFOT) (according to EN 1427). The elastic recovery at $25^{\circ} \mathrm{C}$ (according to EN 13398) was evaluated by the percentage of recoverable strain measured after elongation during a conventional ductility test.

Storage stability was determined using metal test tubes $\Phi 25 \mathrm{~mm} \times 160 \mathrm{~mm}$. The samples of asphalt in aluminum tubes were heated in a vertical position at 180 for 72 hours. After cooling, the aluminum coating was removed and the sample was cut into 3 parts. The middle part was discarded and penetration and softening tests were carried out for the lower and upper parts (difference between penetration top/penetration bottom as delta Pen25 and difference between $\mathrm{SP}_{\mathrm{R} \& \mathrm{~B}}$ top/SP $\mathrm{R}_{\mathrm{R} \& \mathrm{~B}}$ as delta $\left.\mathrm{SP}_{\mathrm{R} \& \mathrm{~B}}\right)$. Retained penetration at $25^{\circ} \mathrm{C}$ after RTFOT (according to EN 1426) and mass change after RTFOT (according to EN 12607-1) were determined for samples heated in rolling thin oven and compared for those of fresh bitumen. Cohesion energies at $5^{\circ} \mathrm{C}$ and $10^{\circ} \mathrm{C}$ were determined by the force ductility method (according to EN 13589 and EN 13703). Under the same tests, additional values were recorded as maximal tensile force $(\mathrm{N})$.

The solid residual was measured by gravimetric method consisting in weighing the dry residue on a sieve.

\section{Results and Discussion}

The bitumen-rubber modification is influenced by the blending/reaction temperature, the time of mechanical mixing, the size and microtexture of the crumb rubber, and the chemical nature of bitumen (concentration of aromatics).

As a cross-linked polymer, rubber does not form a homogeneous solution with bitumen. Three dimensional networks of crumb rubber reinforced by carbon black absorb the light oils from the bitumen causing their swelling and softening [23]. For this reason, in some technologies devulcanized or partially devulcanized rubber was used as modifiers. At elevated temperatures, some of the polysulfide and disulfide bonds in the rubber are converted to monosulfide bonds, which lead to the formation of uncured rubber [24]. In devulcanized form, rubber can be treated as a thermoplastic polymer.

In the studies presented here both devulcanized rubber and synthetic poly(butadiene) (PB) were used as bitumen modifier. PB was preliminarily diluted in biodiesel. It could not be added as solid polymer because at elevated temperatures, it tends to cross-link. Rubber was added as a 0 $0.4 \mathrm{~mm}$ and $0-0.8 \mathrm{~mm}$ granules.

Modifications of bitumen with $\mathrm{PB}$ and devulcanized rubber in the presence of sulfur donor were carried out in 190 and $220^{\circ} \mathrm{C}$ [19-21]. The influence of modification time on the concentration of insoluble residue is presented in Tables 1 and 2. The influence of modification time on the 
TABLE 1: Bitumen modification at $190^{\circ} \mathrm{C}$.

\begin{tabular}{|c|c|c|c|c|c|c|}
\hline \multirow{2}{*}{ Sample no. } & \multicolumn{4}{|c|}{ Modifiers (\%) } & \multirow{2}{*}{ Modification time (h) } & \multirow{2}{*}{ Residue after devulcanization (\%) } \\
\hline & Rubber 0.4 & Rubber 0.8 & PB solution & Sulfur donor & & \\
\hline 1 & 10 & - & 3 & 0.07 & 2 & 7.2 \\
\hline 2 & 10 & - & 3 & 0.07 & 4 & 5.9 \\
\hline 3 & - & 10 & 3 & 0.07 & 8 & 6.1 \\
\hline 4 & 10 & - & 3 & 0.07 & 16 & 4.5 \\
\hline 5 & - & - & 3 & 0.07 & 2 & 1.8 \\
\hline 6 & - & - & 10 & 0.07 & 2 & 2.6 \\
\hline
\end{tabular}

TABLE 2: Bitumen modification at $220^{\circ} \mathrm{C}$.

\begin{tabular}{|c|c|c|c|c|c|c|}
\hline \multirow{2}{*}{ Sample no. } & \multicolumn{4}{|c|}{ Modifiers (\%) } & \multirow{2}{*}{ Modification time (h) } & \multirow{2}{*}{ Residue after devulcanization (\%) } \\
\hline & Rubber 0.4 & Rubber 0.8 & PB solution & Sulfur donor & & \\
\hline 7 & 15 & - & 3 & 0.07 & 2 & 5.3 \\
\hline 8 & 15 & - & 3 & 0.07 & 4 & 4.0 \\
\hline 9 & - & 15 & 3 & 0.07 & 4 & 5.3 \\
\hline 10 & 15 & - & 3 & 0.07 & 8 & 3.4 \\
\hline 11 & - & 15 & 3 & 0.07 & 8 & 3.8 \\
\hline 12 & 15 & - & 3 & 0.07 & 16 & 2.8 \\
\hline 13 & - & 15 & 3 & 0.07 & 16 & 3.7 \\
\hline
\end{tabular}

percentage concentration of residue is evident at $190^{\circ} \mathrm{C}$. With the increase of modification time, the amount of insoluble residue decreased which means that devulcanization of rubber took place (Figure 1). After $16 \mathrm{~h}$ devulcanization time, only $4.5 \%$ of insoluble residue remained. It contained carbon black and residues of rubber whose remains were not devulcanized. Decrease of residue concentration with increase of reaction time is also visible for sample no. 3 which contained coarser rubber $(0-0.8 \mathrm{~mm})$. In this case, devulcanization process ran more slowly.

In $220^{\circ} \mathrm{C}$, the concentration of rubber was increased to $15 \%$. Similarly to the temperature $190^{\circ} \mathrm{C}$, increase of reaction time was accompanied by decrease of residual solid. Depending on the grain size of rubber, the devulcanization process should run faster or slower. For the $0-0.4 \mathrm{~mm}$ granulation rubber, the amount of insoluble residue decreased from $5.3 \%$ to $2.8 \%$, whereas for sample no. 11 with rubber $0-0.8 \mathrm{~mm}$, it was $3.7 \%$.

The properties of bitumen after modification are presented in Tables 3 and 4 . For samples modified at $190^{\circ} \mathrm{C}$, increase of modification time caused rather insignificant changes of properties (Table 3 ). Penetration at $25^{\circ} \mathrm{C}$ changed in the range of $66-71$ units $(0.1 \mathrm{~mm})$. When samples with rubber of $0-0.4 \mathrm{~mm}$ are taken into account, irrelevant decrease of penetration values was observed. Increase in modification time was paralleled by increase in ring and ball (R\&B) softening points and improvement in lowtemperature properties tested with Fraass breaking points. Softening points for samples modified for more than $2 \mathrm{~h}$ achieved values that meet the standards (EN 14023, Polish National Annexe for PMB 45/80-55). A similar tendency was observed for their elastic recoveries at $25^{\circ} \mathrm{C}$.

Stability of samples in tube test, expressed as penetration top/bottom, grew with the increase of modification time at $190^{\circ} \mathrm{C}$ whereas that for samples modified at $220^{\circ} \mathrm{C}$ insignificantly decreased (Figure 2). Simultaneously, the delta
$\mathrm{SP}_{\mathrm{R} \& \mathrm{~B}}$ (difference between $\mathrm{SP}_{\mathrm{R} \& \mathrm{~B}}$ at top and bottom of the tube) decreased, which was a very positive phenomenon. Similar behavior can be observed for the delta $\mathrm{SP}_{\mathrm{R} \& \mathrm{~B}}$ of the samples modified at $220^{\circ} \mathrm{C}$.

Table 3 also presents the data obtained after the rolling thin film oven test (RTFOT). This test represents an aging potential of the binder, especially in simulating binder's thin film during contact with the surface of very hot aggregates in the presence of air. From these data, one can see that with increase of modification time, an insignificant increase of retained penetration at $25^{\circ} \mathrm{C}$ after RTFOT is observed whereas softening point R\&B after RTFOT and mass change after RTFOT show a downward trend. It is important that for this series of samples, mass changes are very small, and with increasing time of modification, they drop from 0.16 to $0.12 \%$.

Modifications without the addition of rubber were also carried out to investigate the effect of the presence of rubber on the properties of bitumen. Reactions lasting 2 hours were performed for several $\mathrm{PB}$ concentrations. Introduction of more than $10 \%$ of $\mathrm{PB}$ was difficult due to drastic decrease in bitumen viscosity. The basic properties of bitumens modified in this way, presented in Table 3, indicate that the lack of rubber has the greatest impact on the values of breaking points.

The data for bitumen samples modified with rubber at $220^{\circ} \mathrm{C}$ presented in Table 4 are not so clear. Values of penetration at $25^{\circ} \mathrm{C}$ are much higher than those obtained for samples modified at $190^{\circ} \mathrm{C}$. Increase of modification time causes that bitumen samples containing rubber of granulation 0-0.4 mm become less soft. Similarly, for samples with rubber $0-0.8 \mathrm{~mm}$ penetrations have increasing tendencies. The softening points for the latter samples increase with the extension of modification time whereas those for samples containing rubber $0-0.4 \mathrm{~mm}$ become smaller. Modification at $220^{\circ} \mathrm{C}$ has positive influence on Fraass breaking points. 


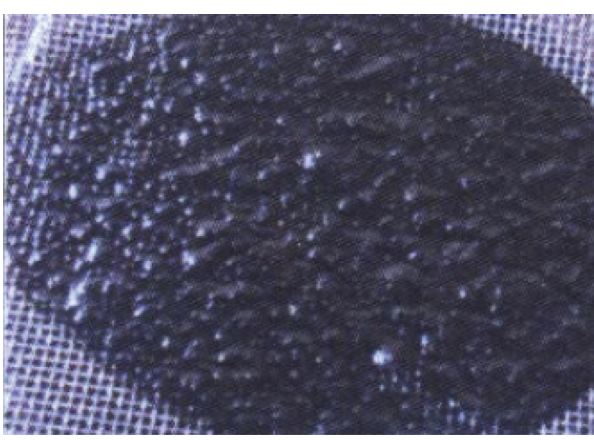

(a)

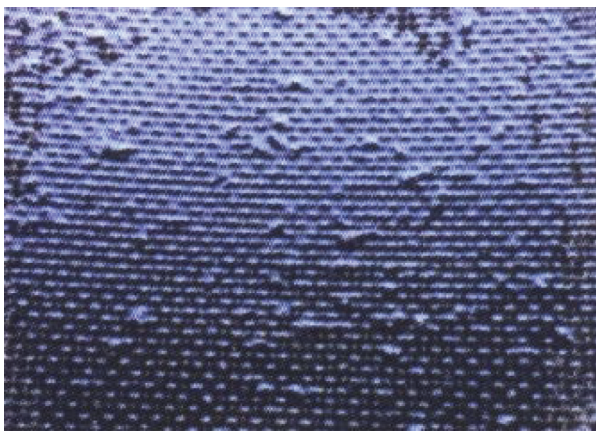

(c)

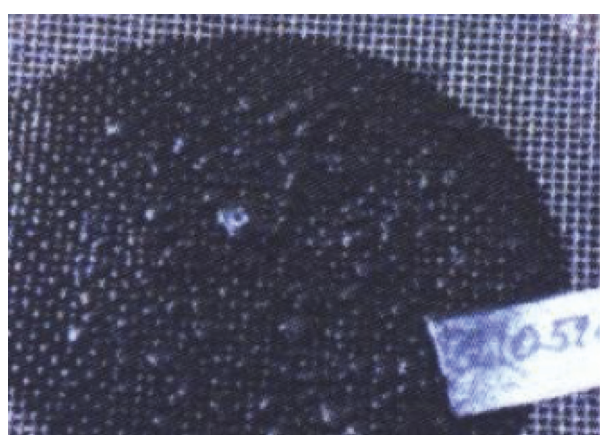

(b)

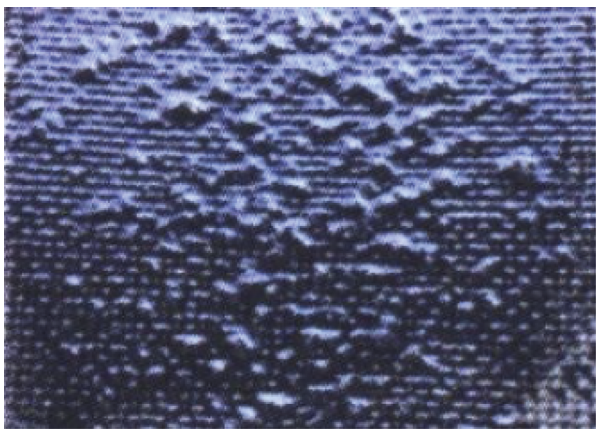

(d)

Figure 1: Residues of samples after filtration through a sieve, $\Phi 0.40 \mathrm{~mm}$. (a) Sample no. 1, (b) sample no. 2, (c) sample no. 3, and (d) sample no. 4.

TABle 3: Properties of bitumen modified at $190^{\circ} \mathrm{C}$.

\begin{tabular}{|c|c|c|c|c|c|c|}
\hline \multirow{2}{*}{ Property } & \multicolumn{6}{|c|}{ Sample no. } \\
\hline & 1 & 2 & 3 & 4 & 5 & 6 \\
\hline Penetration at $25^{\circ} \mathrm{C}(0.1 \mathrm{~mm})$ & 71 & 69 & 66 & 69 & 60 & 68 \\
\hline Softening point $(\mathrm{R} \& \mathrm{~B})\left({ }^{\circ} \mathrm{C}\right)$ & 52.0 & 56.4 & 57 & 55.6 & 55.0 & 53.7 \\
\hline Penetration index & 0.20 & 1.10 & 1.10 & 0.90 & - & - \\
\hline Fraass breaking point $\left({ }^{\circ} \mathrm{C}\right)$ & -20 & -22 & -22 & -23 & -14 & -17 \\
\hline Elastic recovery at $25^{\circ} \mathrm{C}(\%)$ & 69 & 74 & 75 & 72 & - & - \\
\hline $\begin{array}{l}\text { Stability (values of penetration top/penetration } \\
\text { bottom) }(0.1 \mathrm{~mm})\end{array}$ & $71 / 76$ & $75 / 81$ & $80 / 83$ & $82 / 83$ & - & - \\
\hline $\begin{array}{l}\text { Delta penetration (difference between top and } \\
\text { bottom of the tube) }(0.1 \mathrm{~mm})\end{array}$ & 5 & 6 & 3 & 1 & - & - \\
\hline Stability (R\&B top/R\&B bottom) & $50 / 58.6$ & $49 / 58.4$ & $48.8 / 50.2$ & $48.2 / 51.2$ & - & - \\
\hline Delta $\mathrm{R} \& \mathrm{~B}\left({ }^{\circ} \mathrm{C}\right)$ & 8.6 & 9.4 & 1.4 & 3.0 & - & - \\
\hline Retained penetration at $25^{\circ} \mathrm{C}$ after RTFOT (\%) & 60.2 & 61 & 60.4 & 61.4 & - & - \\
\hline Increasing of softening point $\mathrm{R} \& \mathrm{~B}$ after RTFOT $\left({ }^{\circ} \mathrm{C}\right)$ & 8.2 & 4.6 & 3.4 & 5.8 & - & - \\
\hline Mass change after RTFOT (\%) & -0.16 & -0.16 & -0.13 & -0.12 & - & - \\
\hline Cohesion energy at $5^{\circ} \mathrm{C}\left(\mathrm{J} / \mathrm{cm}^{2}\right)$ & 3.5 & 3.6 & 4.8 & 4.1 & - & - \\
\hline Cohesion energy at $10^{\circ} \mathrm{C}\left(\mathrm{J} / \mathrm{cm}^{2}\right)$ & 2.0 & 2.3 & 2.5 & 2.0 & - & - \\
\hline Maximal tensile force at $5^{\circ} \mathrm{C}(\mathrm{N})$ & 25.3 & 21.0 & 32.0 & 27.0 & - & - \\
\hline Maximal tensile force at $10^{\circ} \mathrm{C}(\mathrm{N})$ & 12.9 & 14.6 & 16.0 & 10.4 & - & - \\
\hline
\end{tabular}

Independent of the time of modification, breaking points for all the studied samples were in the range of -26 to $-28^{\circ} \mathrm{C}$. These data suggest that modification at $220^{\circ} \mathrm{C}$ leads to the creation of a more homogeneous bitumen structure. At this temperature, the degree of degradation of the rubber is greater than that at $190^{\circ} \mathrm{C}$. Rather high values of elastic recoveries also confirm the effectiveness of the modification process but samples modified at $220^{\circ} \mathrm{C}$ behave a bit differently. Elastic recoveries for samples containing 0$0.4 \mathrm{~mm}$ rubber decrease with increasing modification time. For samples containing $0-0.8 \mathrm{~mm}$ rubber, elastic recovery decreases first and next increases. It will be remembered that the temperature $220^{\circ} \mathrm{C}$ is suitable for re-cross-linking of rubber and $\mathrm{PB}$ linear polymer, the more so as the sulfur donor was added to this system. Under these conditions, a homogeneous structure of the polymer network is created, 
TABle 4: Properties of bitumen modified at $220^{\circ} \mathrm{C}$.

\begin{tabular}{|c|c|c|c|c|c|c|c|}
\hline \multirow{2}{*}{ Property } & \multicolumn{7}{|c|}{ Sample no. } \\
\hline & 7 & 8 & 9 & 10 & 11 & 12 & 13 \\
\hline Penetration at $25^{\circ} \mathrm{C}(0.1 \mathrm{~mm})$ & 80 & 78 & 80 & 104 & 96 & 97 & 86 \\
\hline Softening point $(\mathrm{R} \& \mathrm{~B})\left({ }^{\circ} \mathrm{C}\right)$ & 55.4 & 52.8 & 49.9 & 48.0 & 50.8 & 51.9 & 51.6 \\
\hline Penetration index & 1.3 & 0.60 & 0.00 & 0.60 & 0.80 & 0.33 & 0.60 \\
\hline Fraass breaking point $\left({ }^{\circ} \mathrm{C}\right)$ & -28 & -27 & -26 & -26 & -28 & -26 & -25 \\
\hline Elastic recovery at $25^{\circ} \mathrm{C}(\%)$ & 70 & 70 & 63 & 62 & 60 & 76 & 63 \\
\hline $\begin{array}{l}\text { Stability (values of penetration top/penetration } \\
\text { bottom) }(0.1 \mathrm{~mm})\end{array}$ & $93 / 88$ & $82 / 80$ & $74 / 76$ & $87 / 96$ & $73 / 76$ & - & $79 / 73$ \\
\hline $\begin{array}{l}\text { Delta penetration (difference between top and } \\
\text { bottom of the tube) }(0.1 \mathrm{~mm})\end{array}$ & 5 & 2 & 2 & 9 & 3 & - & 6 \\
\hline Stability (R\&B top/R\&B bottom) & $50.2 / 58.2$ & $52.0 / 57.4$ & $52.8 / 60.6$ & $52.4 / 46.5$ & $52.2 / 54.0$ & $51.0 / 58.8$ & $51.6 / 56.0$ \\
\hline Delta $\mathrm{R} \& \mathrm{~B}\left({ }^{\circ} \mathrm{C}\right)$ & 8 & 5.4 & 9.2 & 6 & 1.8 & 3.4 & 4.4 \\
\hline Retained penetration at $25^{\circ} \mathrm{C}$ after RTFOT (\%) & 62.4 & 60.5 & 61.2 & 55.0 & 58.0 & 66.0 & 60.2 \\
\hline Increasing of softening point R\&B after RTFOT $\left({ }^{\circ} \mathrm{C}\right)$ & 7.0 & 7.7 & 11.4 & 7.0 & 7.2 & 8.4 & 8.6 \\
\hline Mass change after RTFOT (\%) & -0.68 & -0.70 & 0.73 & 0.84 & 0.64 & 0.24 & -0.47 \\
\hline Cohesion energy at $5^{\circ} \mathrm{C}\left(\mathrm{J} / \mathrm{cm}^{2}\right)$ & 2.9 & 3.1 & 3.3 & 1.1 & 2.6 & - & 2.3 \\
\hline Cohesion energy at $10^{\circ} \mathrm{C}\left(\mathrm{J} / \mathrm{cm}^{2}\right)$ & 1.3 & 1.5 & 1.4 & 1.1 & 1.1 & - & 1.3 \\
\hline Maximal tensile force at $5^{\circ} \mathrm{C}(\mathrm{N})$ & 17.8 & 17.5 & 19.4 & 14.3 & 16.3 & - & 23 \\
\hline Maximal tensile force at $10^{\circ} \mathrm{C}(\mathrm{N})$ & 9.0 & 9.3 & 7.7 & 7.0 & 7.5 & - & 10.5 \\
\hline
\end{tabular}

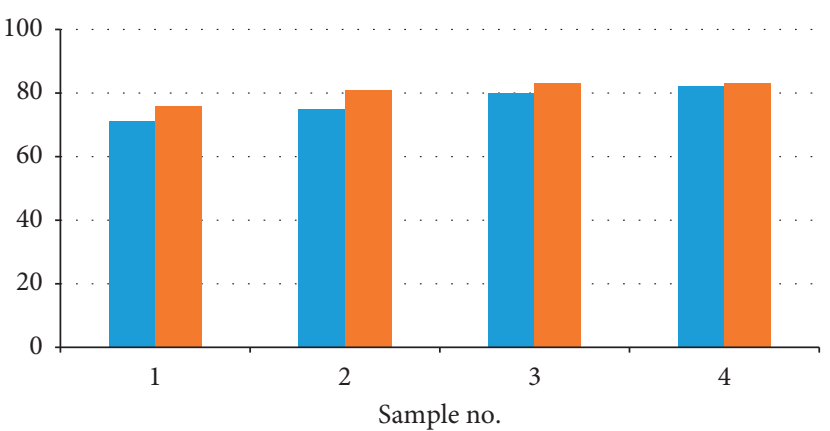

(a)

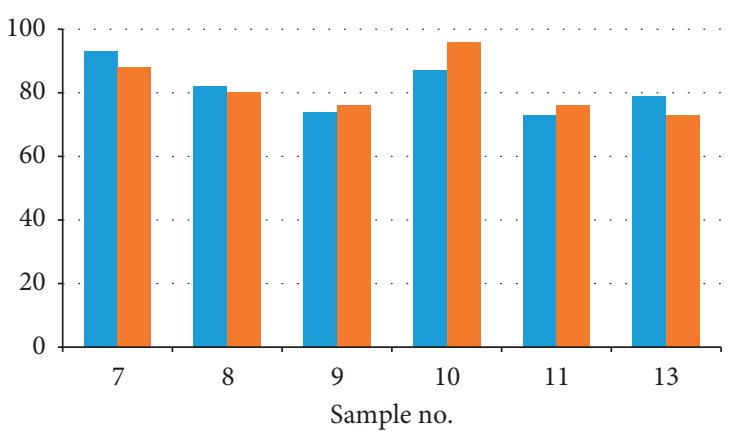

(b)

FIgure 2: Stabilities of samples modified at $190^{\circ} \mathrm{C}$ (a) and $220^{\circ} \mathrm{C}(\mathrm{b})$.

in which bitumen is dispersed. Probably for samples with $0-0.4 \mathrm{~mm}$ rubber, $8 \mathrm{~h}$ modification is sufficient to achieve such effect whereas $0-0.8 \mathrm{~mm}$ rubber degrades slowly, and a uniform structure is obtained after $16 \mathrm{~h}$.

Values of delta penetration and retained penetration after RTFOT additionally confirm the appearance of uniform homogeneous phase. Such bitumens retain their viscoelastic properties at low temperatures and do not flow at higher temperatures at extended load. Independent of modification time, they exhibit resistance to aging. The values of penetration indices are also very promising. According to Ehinola et al. [21], penetration index represents a quantitative measure of the response of bitumen to variation in the temperature. Knowing the penetration index of a particular bitumen, it is possible to predict its behavior in an application. IP values should be around -3 for high temperature susceptible bitumens to around +7 for highly blown low-temperature susceptible bitumen.

Cohesion energies at $5^{\circ} \mathrm{C}$ and $10^{\circ} \mathrm{C}$ determined by force ductility method change between 1.1 and $4.8 \mathrm{~J} / \mathrm{cm}^{2}$ and are rather independent of temperature and time of modification whereas those of maximal tensile forces have larger values for samples modified at $190^{\circ} \mathrm{C}$. These results correspond to earlier conclusions that the proposed process creates modified bitumens with homogeneous and spatially stable structures.

\section{Conclusions}

In order to reduce the cost of preparing polymer modified bitumen, it was proposed to replace part of poly(butadiene) with the waste product: recycled rubber. In this process, rubber in a degraded form is a substrate for the production of PMB.

Pre-devulcanized rubber was next used for creating the joint net with polybutadiene in the process of cross-linking. The devulcanization and cross-linking were carried out at different times at temperatures $190^{\circ} \mathrm{C}$ and $220^{\circ} \mathrm{C}$. The modification process carried out at $220^{\circ} \mathrm{C}$ with $10 \%$ of rubber content is very fast, whereas for samples with $15 \%$ of rubber, 
the optimal modification time is 8 hours. Modification at $190^{\circ} \mathrm{C}$ requires a longer time.

Most of the obtained products meet all standards (PMB 45/80-55 and PG 70-22 according to AASHTO-MP1). Particularly noteworthy is their behavior at low temperatures.

\section{Data Availability}

The data used to support the findings of this study are available from the corresponding author upon request.

\section{Conflicts of Interest}

The authors declare that they have no conflicts of interest.

\section{Supplementary Materials}

The results of the research of the samples with the numbers in the first experimental data refers to Table 3 and in the second to Table 4. (Supplementary Materials)

\section{References}

[1] Y. Becker, M. P. Mendez, and Y. Rodriquez, "Polymer modified asphalt," Vision Tecnologica, vol. 9, pp. 39-50, 2001.

[2] L. H. Lewandowski, "Polymer modification of paving asphalt binders," Rubber Chemistry and Technology, vol. 67, no. 3, pp. 447-480, 1994.

[3] M. A. Quddus, S. N. Sarwar, and K. Fasihullah, "The chemical composition of catalytic air blown asphalt," Fuel, vol. 74, no. 5, pp. 684-689, 1995.

[4] H. Ajideh, A. Rangel, and H. Bahia, "Can chemical modification of paving asphalts be equated to polymer modification? A laboratory study," Transportation Research Record: Journal of the Transportation Research Board, vol. 1875, pp. 56-69, 2004.

[5] Y. Becker, A. J. Müller, and Y. Rodriguez, "Use of rheological compatibility criteria to study SBS modified asphalts," Journal of Applied Polymer Science, vol. 90, no. 7, pp. 1772-1782, 2003.

[6] S. Tapkin and Ş. Özcan, "Determination of the optimal polypropylene fiber addition to the dense bituminous mixtures by the aid of mechanical and optical means," Baltic Journal of Road and Bridge Engineering, vol. 7, no. 1, pp. 22-29, 2012.

[7] G. Polacco, S. Berlincioni, D. Biondi, J. Stastna, and L. Zanzotto, "Ashalt modification with different polyethylenebased polymers," European Polymer Journal, vol. 41, no. 12, pp. 2831-2844, 2005.

[8] O. I. Slavgorodskaya, V. G. Bondaletov, and Y. P. Ustimenko, "Bitumen modification," Advanced Materials Research, vol. 880, pp. 3-6, 2014.

[9] J. Zhu, B. Birgisson, and N. Kringos, "Polymer modification of bitumen: advances and challenges," European Polymer Journal, vol. 54, pp. 18-38, 2014.

[10] T. Alataş and M. Yilmaz, "Effects of different polymers on mechanical properties of bituminous binders and hot mixtures," Construction and Building Materials, vol. 42, pp. 161-167, 2013.

[11] I. Gawel and L. Slusarski, "Use of recycled tire rubber for modification of asphalt," Progress in Rubber, Plastics \& Recycling Technology, vol. 15, pp. 235-248, 1999.
[12] I. Gaweł, P. Radziszewski, K. J. Kowalski, and J. B. Król, "Rubber Modified Bitumen," in Polymer Modified Bitumen: Properties and Characterisation 2011, T. McNally, Ed., Woodhead Publishing Limited, Cambridge, UK, 2011.

[13] N. Vichitcholchai, J. Panmai, and N. Na-Ranong, "Modification of asphalt cement by natural rubber for pavement construction," Rubber Thai Journal, vol. 1, pp. 33-40, 2012.

[14] K.-D. Jeong, S.-J. Lee, S. N. Amirkhanian, and K. W. Kim, "Interaction effects of crumb rubber modified asphalt binders," Construction and Building Materials, vol. 24, no. 5, pp. 824-831, 2010.

[15] N. S. Mashaan, A. H. Ali, M. R. Karim, and M. Abdelaziz, "An overview of crumb rubber modified," International Journal of the Physical Sciences, vol. 7, no. 2, pp. 166-170, 2012.

[16] X. Wang, "Study of rubber asphalt modification mechanism," Advanced Materials Research, vol. 194-196, pp. 844-847, 2011.

[17] H. Wang, X. Liu, P. Apostolidis, and T. Scarpas, "Review of warm mix rubberized asphalt concrete: towards a sustainable paving technology," Journal of Cleaner Production, vol. 177, pp. 302-314, 2018.

[18] S. Saiwari, W. K. Dierkes, J. W. M. Noordermeer, and A. Blume, "Best practice for the devulcanization of sulfurcured SBR rubber," in Proceedings of International Rubber Conference, pp. 1-17, DKT, Nürnberg, Germany, 2015.

[19] L. K. Hunt and R. R. Kovalak, "Devulcanization of cured rubber," US Patent No. 5891926 A, The Goodyear Tire \& Rubber Company, Akron, OH, USA, 1998.

[20] B. D. Andrew, B. R. Neil, L. Sunggyu, and C. K. Lee, "Devulcanization of cured rubber," US Patent No. 0132841 A1, The Goodyear Tire \& Rubber Company, Akron, OH, USA, 2004.

[21] B. Gawdzik and T. Matynia, Patent Application, PL No. 229418, 2013.

[22] O. A. Ehinola, O. A. Falode, and G. Jonathan, "Softening point and penetration index of bitumen from parts of Southwestern Nigeria," NAFTA, vol. 63, no. 9-10, pp. 319-323, 2012.

[23] A. Coomarasamy, S. Manolis, and S. Hesp, "High temperature performance of scrap tire rubber modified asphalt concrete," American Chemical Society Division of Fuel Chemistry, vol. 41, pp. 1322-1326, 1996.

[24] https://www.tut.fi/ms/muo/vert/6_elastomeric_materials/ recycling_methods_devulcanization.htm. 

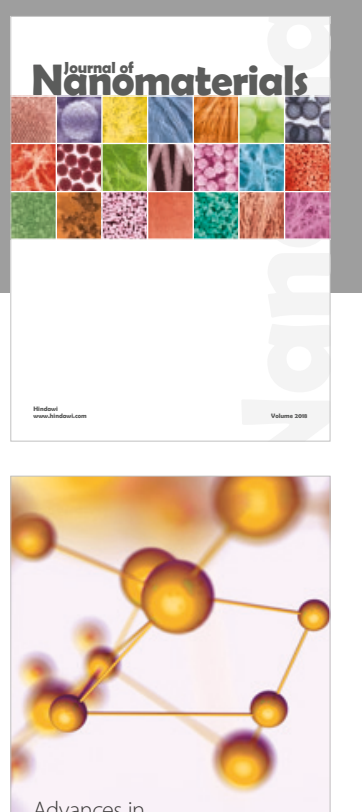

Physical Chemistry
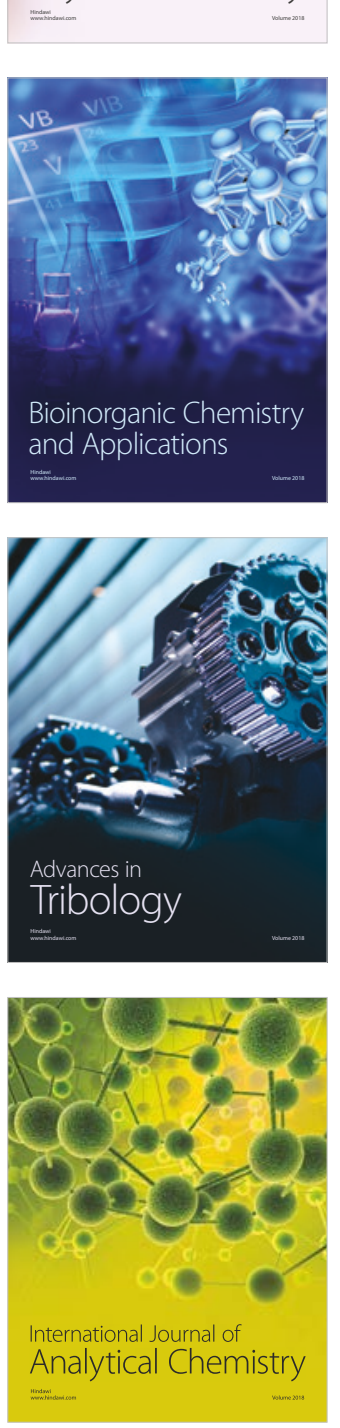

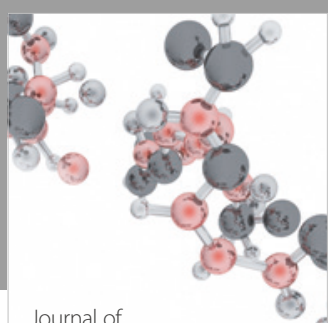

Analytical Methods

in Chemistry

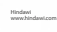

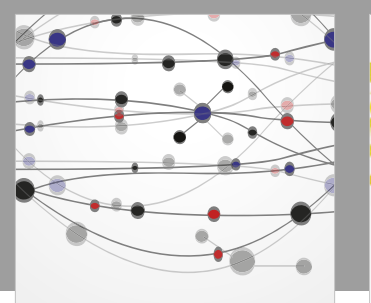

The Scientific World Journal

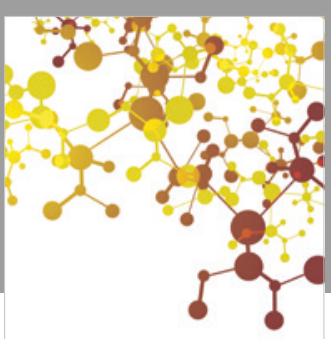

Journal of

Applied Chemistry
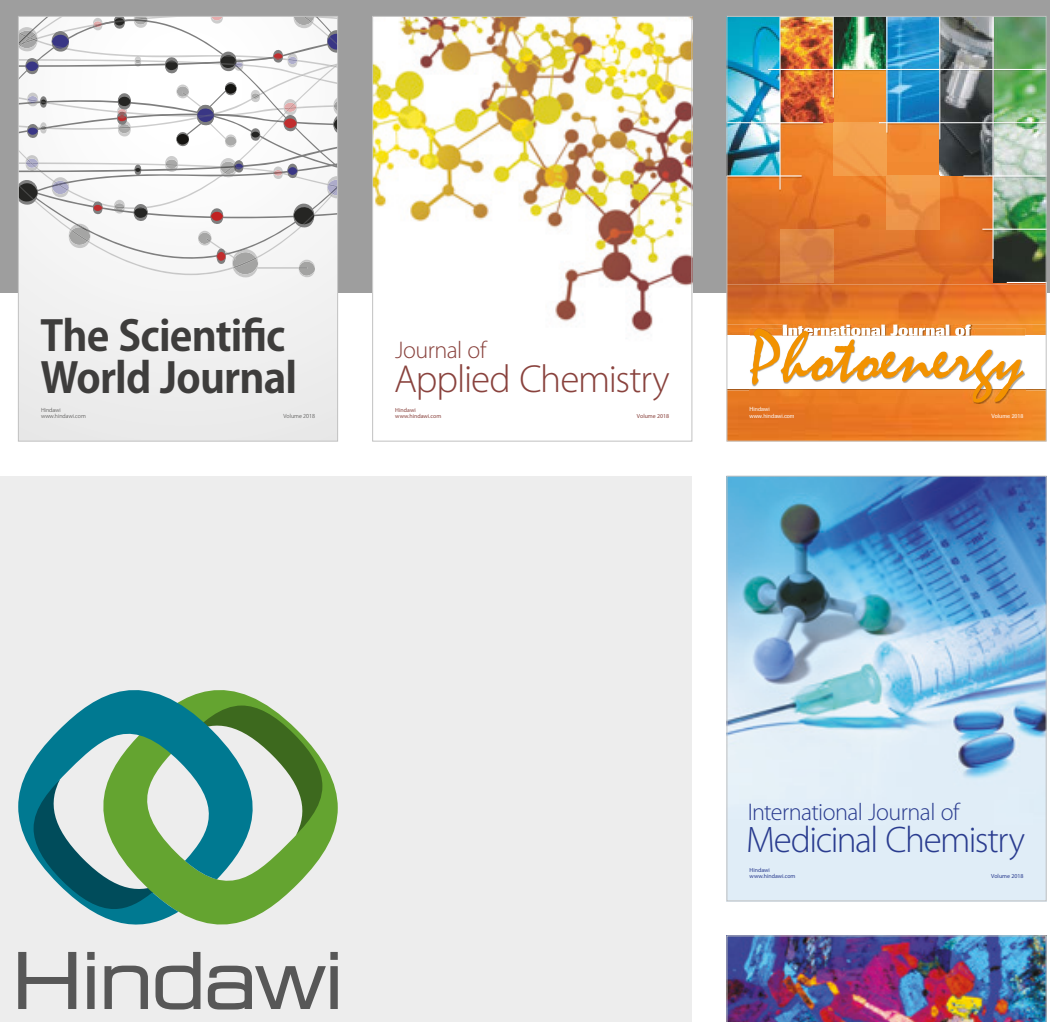

Submit your manuscripts at

www.hindawi.com
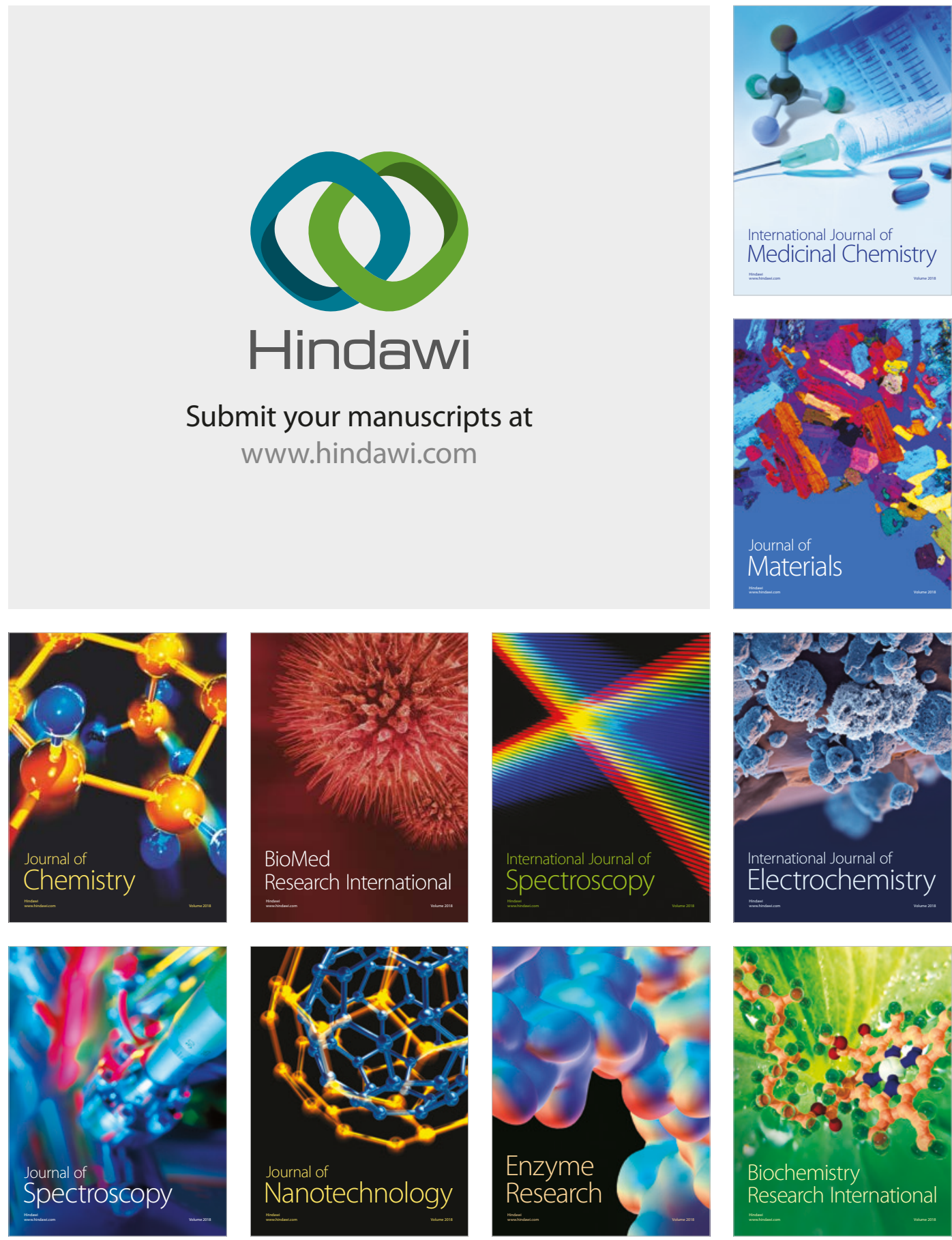
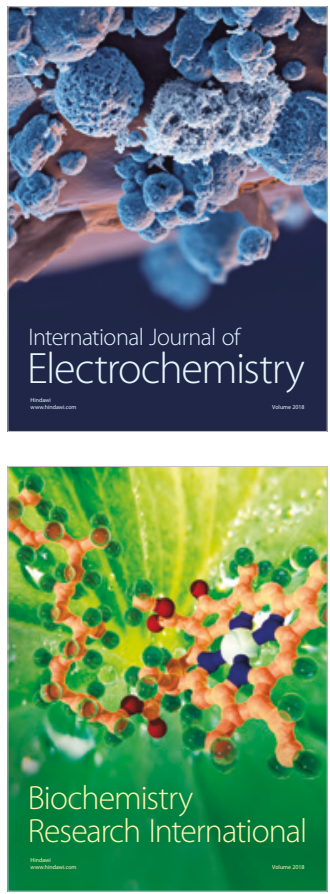